\title{
Kernos
}

Revue internationale et pluridisciplinaire de religion grecque antique

30 | 2017

Varia

\section{Envy, Poison, and Death. Women on Trial in Classical Athens}

\section{Emilio Suárez de la Torre}

URL: http://journals.openedition.org/kernos/2530

DOI: $10.4000 /$ kernos. 2530

ISSN: 2034-7871

\section{Publisher}

Centre international d'étude de la religion grecque antique

\section{Printed version}

Date of publication: 1 October 2017

Number of pages: $342-345$

ISSN: 0776-3824

\section{Electronic reference}

Emilio Suárez de la Torre, « envy, Poison, and Death. Women on Trial in Classical Athens », Kernos [Online], 30 | 2017, Online since 01 October 2017, connection on 24 September 2020. URL : http:// journals.openedition.org/kernos/2530; DOI : https://doi.org/10.4000/kernos.2530

This text was automatically generated on 24 September 2020.

Kernos 


\title{
Envy, Poison, and Death. Women on Trial in Classical Athens
}

\author{
Emilio Suárez de la Torre
}

\section{REFERENCES}

Esther EIDINOW, Envy, Poison, and Death. Women on Trial in Classical Athens, Oxford, Oxford

University Press 2016. 1 vol. 14 × 22 cm, XII+421 p. ISBN 978-0-19-956260-2.

1 This is an original work with a rigorous methodology. It affords an insight into Greek society and at the same time patterns of human behaviour in general, and so its interest goes beyond Athenian fourth-century BCE society, the core on which it is based. In effect, Esther Eidinow's new book, which has several points of contact with her previous one, ${ }^{1}$ can be said to take as its lemma the trials of three women: Theoris of Lemnos, Ninon and Phryne. Their trials - which resulted in death sentences in the first two cases and are reinforced with further references to similar episodes involving anonymous 'dangerous women' in Ancient Greece - share elements that serve the author to conduct a thorough overview of how a particular society and its individuals react in certain situations that seem to upset the balance of that society. The feeling of envy (Gk. $\varphi \theta$ óvo ) and the dynamics generated by rumours (or to use a more colloquial term, gossip) play an essential role in this process. The book, which forms part of the fruitful line of study of emotions in ancient societies, is of unquestionable socioanthropological value, not only with regard to classical Greece but also as a contribution to the dynamics of the relationship between the individual and society in any period or context.

2 The book is divided into four parts. Part 1 ("The Women", p. 3-37) sets forth and analyses the evidence that is preserved on the cases mentioned. Although they follow similar parameters, there are some differences in the nature of the cases. Nevertheless, they also share lack of unanimity in the definition of the charges pressed in each case.

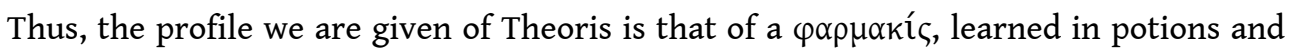


incantations (Demosthenes describes her activity as $\mu \alpha \gamma \gamma \alpha v \varepsilon v ́ \varepsilon ı v)$, although she is also

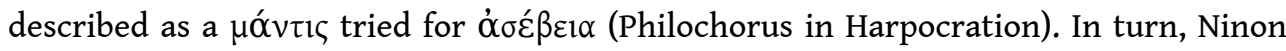

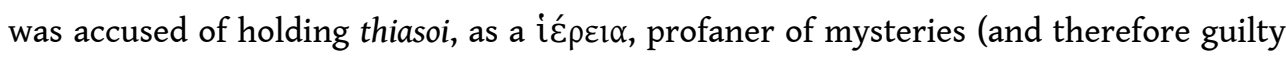

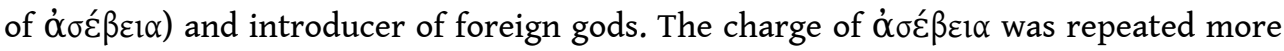
clearly in the case of Phryne, together with the mention of the introduction of a 'new' god (probably due to the false interpretation of the divinity Isodaites). The not always clear profile of these women's practices is completed with the examples of a yuvì uó yo or soothsayer mentioned in Aesop's Fables, Antiphon's case Against the Stepmother for Poisoning (by means of a pí $\lambda \tau \rho o v$ ) and Aretaphila's attempted murder of Nicocrates, tyrant of Cyrene, narrated by Plutarch. The A. poses the problem of the exact reason for these convictions, as some lack of delimitation is observed in the possible charges brought against the defendants : impiety, magic, and the introduction of new divinities. More than once, the A. rightly recalls the trial against Socrates: social control hovers around all of them and affects the accused in a way that is not always consistent. Given that the episode of Aretaphila includes a reference to the fact that she had felt herself to be a target of phthonos, the A. draws on a fourth-century BCE defixio (NGCT 24) in which the person who wrote it claimed that he or she may have been a victim of phthonos, and so in turn proceeded to 'bind' all his or her enemies. In view of the relationship between phthonos and the accusation of the use of pharmaka, the A. takes this text as a starting point for demonstrating the social dynamics we find in the charges against Theoris, Ninon and Phryne.

Consequently, Part 2 is dedicated to the concept of phthonos (p. 69-163). After analysing several theories and definitions on emotions and reaching the conclusion that "emotions are cognitive, linguistic, embodied, and social manifestations - all of which relate to, and shape, each other" (p. 101), the A. goes on to study some testimonies on phthonos, in order to contextualise this "emotion" in the chosen historical period. Her main sources (although they are not the only ones she uses) are of a quite different nature: on the one hand, Pindar's epinikia, and on the other, fourth-century BCE forensic speeches. The analysis of the first group focuses above all on the view of the epinikia expressed in socio-economic terms by Leslie Kurke, with the consideration of reciprocity and the relationship between the return of the victor and the effect of the victory on the citizens. In the same way, "the discourse of phthonos in the forensic corpus shows how this emotion was inseparable from the networks of relationships in which it occurred" (p.125). These texts show not only the effect of 'envy' of others' success, but also the eagerness to destroy their public recognition and ruin their reputation that comes with it. Both Pindar and the speeches highlight the tensions that disrupt a reciprocal relationship between the members of a society. The A. also reviews the concept of 'envy of the gods' and its historical evolution, in which she notes a progressive link with the concept of tyche. To complete the picture, we find a section on 'occult aggression', focusing on the cases of Gemellus Horion and Libanius. In the conclusion to this part, the author underlines the importance of the spreading of the emotion of phthonos through 'gossip' (i.e., 'phthonos talk').

This is the phenomenon that occupies Part 3 ("Poison", p. 166-262). After briefly resuming the matter of Socrates and the references to philtra and pharmaka, the A. summarises various theories on the phenomenon of gossip and the three stages in which it manifests itself: circulation, formation of meaning (cultural coining) and action. She then goes on to analyse several varieties of gossip with testimonies taken 
from the Greek world, including a study of the 'lexicon of rumour', from its simplest expression to the prophetic ( $\varphi \eta n \eta)$. She also considers the perspective of this key phenomenon in the organisation of social taxonomies and the defence of a group's identity. To this effect she reviews several literary testimonies (from Semonides to drama). A significant section of this part is devoted to the configuration and effects of rumour both in the public sphere (with detailed recourse to the orators), in which ultimately a trend is created towards what the author describes as a "hypervigilant environment" (p. 209), and in the private sphere. In the latter the main material is in the form of epitaphs and especially defixiones, documents that bear witness to the sensation of anguish caused in individuals by the feeling of being beleaguered by slander and having been unfairly accused as a result of it. This part includes an original proposal on the features of curse tablets that is undoubtedly open to controversy. Namely, in opposition to the judgement of the intention of these tablets in terms of the concept of Schadenfreude (Versnel), the author considers that they take the elements that describe the torment of the victim from the realm of physical punishment (in particular apotumpanismos) and the public humiliation that this entailed. One of the foundations for this posture is the use of the theoretical basis afforded by 'conceptual metaphor theory' (Lakoff-Johnson). On this basis, the author proposes that spells be regarded as examples of 'manipulative magic' (p. 246), which blends together several patterns and concepts, specifically those of the ritual space and those of the judicial space in which the penalties imposed are enforced. In other words, judicially accepted processes of punishment are associated with the punishment wished on the victim in these spells. This merging of spells and judicial activity is the perspective that E.E. sees as completing and transcending the mere consideration of the intention of Schadenfreude. All this helps to make the phthonos-gossip chain give way to the possibility of a punishment that acquires the status of 'civic' in that context.

5 Thus we come to Part 4 ("Death", p. 263-335). It seeks to answer the question of how the situation was reached in which these three women, Theoris, Ninon and Phryne, were brought to trial and two of them sentenced to death, given that none of them played a leading role in public life. Why was such collective risk perceived in these cases? To begin with, the A. reviews the situation of Athens in the wake of the Peloponnesian War, in which the situation is very negative in several ways: loss of population (and control over territories), and poverty. Eidinow performs a thorough analysis of aspects such as financial distress (with reforms such as that of the symmories) and the supply problems experienced in the fourth century BCE. One interesting section for research purposes is that dealing with the increase in immigrant population. This resulted in a restriction in the recognition of citizenship, with particular detriment to more disadvantaged social groups such as women, whose situation is summarised well in the section entitled "Dependence and Vulnerability" (p. 292-311), which also examines the situation of widows and orphans. In this context the author draws our attention to the cases of Neaera and Lais, which eloquently illustrate the situation. This section includes a rather surprising mythical reference to Manto, daughter of Tiresias, described as a story that connects "experiences of dependency on male relatives, enforced itinerancy, enforced sexual service" (p. 308), and furthermore introduces the dimension of mantic powers. In turn, this mention brings the author to remark on the case of Diotima, as an example of women who in the fourth century BCE "engendered great anxiety" (p. 310). So we come to the last section of this part ("Dangerous Women"), in which the cases of the women in question are 
resumed, now with the addition of some examples of these dangerous women, such as Alce, Phile (both known from different speeches of Isaeus), again Neaera (and her daughter Phano), and Sinope: in all of them, to a greater or lesser extent, coincidences accumulate in reference to their nature as non-citizens, prostitutes, supposed manipulators of men with a view to enriching themselves or passing themselves off as citizens, performers of improper religious or even magical practices, and so on. In this way, they are all portrayed as a danger not only to the men with whom they interacted, but also to the city as a whole. E.E. notes that this negative model we are given above all by the forensic speeches is complemented inversely by the tendency to portray an idealised oikos on women's grave stelai and epitaphs, with special emphasis on the role of the wife. The conclusion, then, regarding the three women with which the book opened, is that, given the socio-political circumstances of the Athens of their time, they were victims of the phthonos-rumour (gossip) sequence: "the cases of Theoris, Ninon, and Phryne suggest that these discourses of risk and real life could collide with devastating results" (p. 327). The book concludes with an epilogue (p. 328-335) that attempts to explain the cases studied in the light of the socio-anthropological concept of 'social trauma', with parallelisms in modern societies. The three women studied would somehow have been victims of the social trauma caused by the Peloponnesian War and its consequences and aftermath among the Athenians. Furthermore, the court of law would have contributed to bring the profile of these 'dangerous women' closer to that of 'witches'. The book is completed with an extensive bibliography (p. 337-379) and the corresponding indices (general and locorum).

6 At the beginning I qualified the work as original and rigorous, and so I consider it to be. Does this mean it is free of objections? I shall briefly set forth some that occurred to me in the course of my reading. I may be mistaken, but I am not so sure that the cases analysed have phthonos as their main underlying motivation. In fact, in the sources for each of them this emotion does not play a leading role (whereas it does in later ones). We can talk of fear, prevention, mistrust, but not clearly envy (or at least not in the usual sense of the word). For example, the examination of the Pindaric poems (perhaps excessively coloured by the explanation of 'economic' reciprocity, based on Kurke's ideas) amply illustrates the concept of phthonos, but I do not know whether it is appropriate to compare it with the cases at hand: neither the historico-social context nor the exact nature of the sentiment of the citizens or rivals that might feel it are transferrable to the cases studied. In short, I perceive something of a conceptual leap.

7 My next objection concerns the interpretation of the formulas of the defixiones exclusively on the basis of evoking torment in the judicial context. I believe there is considerably more to it than this, especially considering the long tradition of the magical value of binding, the use of this terminology and that of torment outside contexts of a negative nature (cf. love spells), and the by no means negligible fact that in general the intention was to bring the victim before the infernal gods. The explanation provided has the support of immediate social circumstances, but then we should talk of a reinterpretation in this context. Furthermore, we cannot exclude the explanation on the basis of the term Schadenfreude (Versnel), at least partly. I conclude this part with two minor details and one grievance. One detail concerns the odd case of lack of consistency when using transcribed terms. For example, it is not correct to say that "the gods are phthoneron" (p.153). The other minor detail is about the way Semonides' text is presented (p. 186-187), without respecting the poetic form : it could have been treated in the same way as the other cases (first the text, then the 
translation). As for the grievance, it is a lamentation over the scant presence of bibliographical references to authors from the non-English-speaking world. I will make just two points on this score. From Marie Delcourt to Marcello Carastro, much has been said (not in English, of course) on the subject of binding spells and defixiones. And is it acceptable to speak of the relationship between poet, victor and audience without mentioning Bruno Gentili?

8 Nonetheless, I reiterate my overall very positive assessment of this contribution to knowledge of Greek society, its perception of emotions and feelings and the role of women in Athenian society. It will undoubtedly be a work of reference from now on.

\section{NOTES}

1. Oracles, Curses, and Risk among the Ancient Greeks, Oxford, 2007.

\section{AUTHORS}

\section{EMILIO SUÁREZ DE LA TORRE}

Universitat Pompeu Fabra - Barcelona 